\title{
Spatial and temporal patterns of microphytobenthic taxa of estuarine tidal flats in the Tagus Estuary (Portugal) using pigment analysis by HPLC
}

\author{
V. Brotas ${ }^{1, *}$, M. R. Plante-Cuny ${ }^{2}$ \\ ${ }^{1}$ Instituto de Oceanografia, Faculdade de Ciencias, Universidade de Lisboa, Campo Grande, P-1700 Lisboa, Portugal \\ ${ }^{2}$ Centre d'Océanologie de Marseille, Université de la Méditerranée, UMR CNRS 6540, Station Marine d'Endoume. \\ rue de la Batterie des Lions, F-13007 Marseille, France
}

\begin{abstract}
Measurements of natural estuarine microphytobenthos communities were carried out in samples of intertidal sediments of the Tagus Estuary (Portugal) by means of pigment analysis by HPLC in order to identify microphytobenthos composition. The relative abundance of taxa was determined by microscopic observations. During spring 16 sites were sampled and 3 of them, differing in sediment grain size and tidal level, werc sited fortnightly for 1 yr. At all sites throughout the year, diatoms were the dominant algal group, evidenced by the relatively high concentrations of chlorophylls $c_{1}+c_{2}$, fucoxanthin, neofucoxanthin, diadinoxanthin, diatoxanthin and $\beta$-carotene. $C h l b$ and diatoxanthin were related with observed euglenophyte populations, zeaxanthin with cyanobacteria, lutein with macrophyte debris and alloxanthin with falling phytoplanktonic cells of cryptophytes. The spatial study allowed a distinction between sites regarding the presence of macrophyte debris, euglenophytes or only diatoms. The temporal survey showed the seasonal trends of diatoms and cyanobacteria and the main periods of plant debris deposition. Pheophytin a and chlorophyllide a concentrations were quite low. Degraded chloropigments were constituted mainly of pheophorbides $a, 9$ of which were quantified. The most abundant among them indicated intensive grazing by macrozoobenthos at the muddy stations
\end{abstract}

KEY WORDS: Chloropigments C Carotenoids HPLC Estuarine mud flats - Tagus - Microphytobenthos Taxonomic markers

\section{INTRODUCTION}

As in phytoplankton studies, chl a concentration in surface sediments gives overall information about the distribution of plant biomass. The HPLC technique, being essentially a separative method, makes it possible to isolate native chl a which can be used as a reliable index of this plant 'living mass' (biomass) of microbenthic algae (Riaux-Gobin et al. 1987, Barlow et al. 1990, Plante-Cuny et al. 1993, Pinckney et al. 1994).

·E-mail: vbrotas@fc.ul.pt
But, microphytobenthos communities are known to present heterogeneous distributions in space (patchiness) as well as in time. Taxonomic composition is usually analysed just qualitatively, as microscopic cells are difficult to count on a large scale. The problem of how to evaluate the taxonomic composition of natural populations is now often handled by the utilization of HPLC pigment analysis in phytoplankton studies (Gieskes 1991, Millie et al. 1993, Quiblier et al. 1994, Andersen et al. 1996, Roy et al. 1996, Jeffrey \& Vesk 1997). In microphytobenthos studies however, taxonomic markers are more difficult to identify, because autochthonous microphytobenthic chloropigments and carotenoids coexist with their degraded forms origi- 
nating from diagenic or biochemical processes (Keely \& Brereton 1986. Bianchi et al. 1988, Buffan-Dubau et al. 1996, Pastoureaud et al. 1996). A vast number of carotenoids originating from macrophytodetritus before and after grazing have been also reported (Abele 1988, Bianchi \& Findlay 1990, Levinton \& McCartney 1991. Abele-Oeschger et al. 1992, Bianchi et al. 1993a and references therein).

Application of HPLC to characterize living sediment microalgal communities has been relatively recent (Riaux-Gobin et al. 1987, Klein \& Riaux-Gobin 1991, Bianchi et al. 1993b, Barranguet et al. 1996) and particularly rare in the intertidal zone (Cariou-Le Gall \& Blanchard 1995).

In a previous paper, Brotas et al. (1995) used chl a measured spectrophotometrically to describe spatial and temporal changes of microphytobenthic biomass in the Tagus Estuary (Portugal). The part played by the microphytobenthos in the estuarine ecosystem appeared to be of major importance. The aim of the present paper is to illustrate the use of the HPLC technique as a powerful tool to determine patterns of spatial and temporal distribution of microphytobenthic community taxa in a great variety of intertidal surface sediments. We present pigment signatures to identify the major taxonomic groups, which were determined by microscopic observations. The distribution of chlorophyll degradation by-products is also described and discussed.

\section{MATERIALS AND METHODS}

Study stations. The Tagus Estuary $\left(38^{\circ} 44^{\prime} \mathrm{N}\right.$, $09^{\circ} 08^{\prime} \mathrm{W}$ ), which runs through the most populated area of Portugal, is a large $\left(320 \mathrm{~km}^{2}\right)$ estuarine ecosystem (Fig. 1). It is a shallow (mean depth of $5 \mathrm{~m}$ ) mesotidal estuary bordered mainly by mud flats. The tidal amplitude ranges from ca 1 to $4 \mathrm{~m}$, so that the intertidal area comprises 20 to $40 \%$ of the total area in neap and spring tides, respectively. The upper littoral zone is occupied by a fringe of salt marsh vegetation, which covers ca 1300 ha (Catarino et al. 1985).

Sampling program. During April and May 1990, 16 sites from 10 stations (nos. 1 to 6 and 11 to 14 ) were sampled. Sites were chosen to cover the widest possible range of situations (salt marsh, muddy and sandy bottoms, different tidal heights) present in the estuarine intertidal area. In the stations which presented
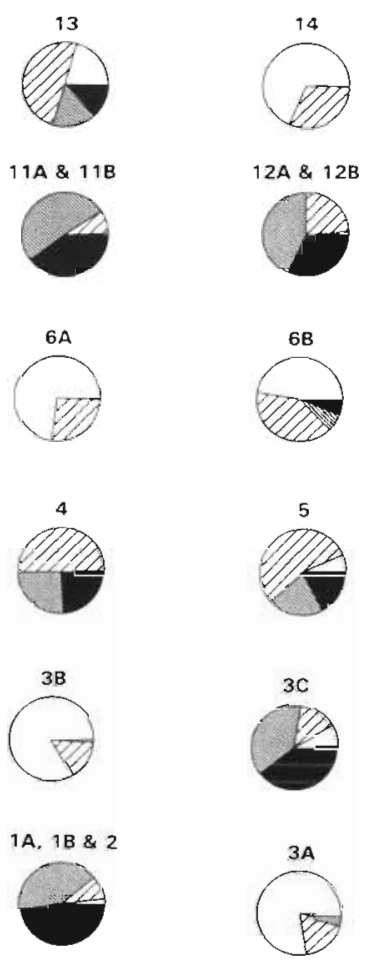

Fig. 1. Location of 10 stations (including 16 sites) in the Tagus Estuary, Portugal. The lower limit of the intertidal area is indicated by the thin line, and marsh zones are shown in grey. Pies represent sediment types of the 6 sites. Black: clay $(<2 \mu \mathrm{m})$; fine hatching: silt ( 2 to $20 \mu \mathrm{m})$; large hatching: fine sand $(0.02$ to $0.2 \mathrm{~mm})$ and white: coarse sand $(0.2$ to $2 \mathrm{~mm})$. Identification code: number of the station plus $\mathrm{A}, \mathrm{B}$ or $\mathrm{C}$ from the highest, middle and lowest tidal position. See Table 1

obvious spatial heterogeneity, 2 or 3 sites were considered (identification code: number of the station, i.e. $1,2,3, \ldots$, plus site letter A, B or C, for the highest, middle and lowest tidal position respectively; Table 1 , Fig. 1). Three sites (at Stns 1 and 3) were selected, each one representing a typical stratum of the ecosystem (Brotas et al. 1995): sites 1B (salt marsh mud), 3B (midshore sandy flat) and $3 \mathrm{C}$ (low tide mud flat), differing in sediment grain size and tidal level, were visited fortnightly from April 1991 to April 1992, to examine seasonal variations.

Sampling and analysis protocol. Sediment cores, collected by hand with a Plexiglas corer $(36 \mathrm{~mm}$ internal diam.), were transported to the laboratory in a cooling box and immediately frozen at $-20^{\circ} \mathrm{C}$ until further processing. The first $\mathrm{cm}$ was sampled for water content, organic matter content (3 replicates) and grain size analyses. A superficial slice of 0 to $5 \mathrm{~mm}$ was sampled from 1 core and freeze-dried for HPLC pigment analysis: a quantity of 0.3 to $3 \mathrm{~g}$ of sediment was used. Some authors (Riaux-Gobin et al. 1987) considered that freeze-drying reduces some pigment concentrations by up to $90 \%$. However, by means of a previ- 
Table 1 Description of sampling sites. Physical and chemical characteristics of sediments. Sampling programs: • spring 1990, - spring 1990 and seasonal survey from April 1991 to April 1992. AFDW: ash free dry weight

\begin{tabular}{|c|c|c|c|c|c|c|}
\hline Site description & $\begin{array}{c}\text { Site } \\
\text { number }\end{array}$ & $\begin{array}{l}\text { Sampling } \\
\text { program }\end{array}$ & $\begin{array}{c}\text { Tidal } \\
\text { height } \\
\text { (m) }\end{array}$ & $\begin{array}{l}\text { Annual } \\
\text { emersion } \\
\text { time }(\%)\end{array}$ & $\begin{array}{c}\text { Water } \\
\text { content } \\
(\%)\end{array}$ & $\begin{array}{c}\text { AFDW } \\
(\%)\end{array}$ \\
\hline Salt marsh under Spartina canopy & $1 \mathrm{~A}$ & - & 3.1 & 81 & 60 & 10.5 \\
\hline Salt marsh mud & $1 \mathrm{~B}$ & $\because \cdot$ & 3.1 & 81 & 67 & 8.3 \\
\hline Salt marsh mud & 2 & $\cdot$ & 2.0 & 44 & 65 & 10.4 \\
\hline Sand under Spartina canopy & $3 \mathrm{~A}$ & - & 3.0 & 77 & 21 & 2.3 \\
\hline Muddy sandy flat & $3 B$ & $\cdot \cdot$ & 2.0 & 44 & 20 & 1.0 \\
\hline Mud flat & $3 \mathrm{C}$ & $\cdot \cdot$ & 1.4 & 23 & 65 & 11.5 \\
\hline Mud flat & 4 & - & 0.7 & 3 & 51 & 8.1 \\
\hline Mud flat & 5 & $\cdot$ & 1.4 & 23 & 50 & 6.8 \\
\hline Muddy sandy flat & $6 \mathrm{~A}$ & $\cdot$ & 1.6 & 31 & 20 & 0.6 \\
\hline Muddy sandy flat & $6 \mathrm{~B}$ & $\cdot$ & 1.6 & 31 & 23 & 1.6 \\
\hline Salt marsh under Spartina canopy & $11 \mathrm{~A}$ & - & 3.4 & 91 & 58 & 11.0 \\
\hline Salt marsh mud & $11 B$ & $\cdot$ & 3.4 & 91 & 70 & 14.5 \\
\hline Salt marsh under Spartina canopy & $12 \mathrm{~A}$ & $\cdot$ & 2.8 & 69 & 58 & 7.8 \\
\hline Salt marsh mud & $12 \mathrm{~B}$ & . & 2.8 & 69 & 57 & 7.2 \\
\hline Muddy sandy flat & 13 & $\cdot$ & 1.4 & 23 & 29 & 3.8 \\
\hline Muddy sandy flat & 14 & $\cdot$ & 1.7 & 34 & 22 & 1.2 \\
\hline
\end{tabular}

ous comparative study of pigment extraction from wet and freeze-dried sediments, we concluded that results obtained from wet samples were highly variable and non-reproducible (Plante-Cuny et al. 1993). Deepfreezing and subsequent thawing before extraction appears to be much more harmful than using freezedried samples. The latter method furthermore allows long-term conservation. Some other problems, also discussed by Plante-Cuny et al. (1993), may occur during extraction or when using the HPLC technique, especially through chlorophyllase action (Jeffrey \& Hallegraeff 1987). Water content was determined as the percentage of water in relation to total fresh weight. Organic matter was measured as percentage of weight loss by ignition $\left(500^{\circ} \mathrm{C}, 2 \mathrm{~h}\right)$ from the $100^{\circ} \mathrm{C}$ dried sediment (ash free dry weight; Table 1). A granulometric analysis was carried out to determine the relative abundance ( $\%$ dry weight) of clay $(<2 \mu \mathrm{m})$, silt, (2 to $20 \mu \mathrm{m})$, fine sand $(0.02$ to $0.2 \mathrm{~mm})$ and coarse sand (0.2 to $2 \mathrm{~mm}$ ) according to the Wentworth scale (Fig, 1).

HPLC analysis. A comprehensive description of HPLC procedures used in the present study (preparation of standards, identification and quantification of chloropigments and carotenoid pigments), adapted from Kraay et al. (1992), is given in Brotas \& PlanteCuny (1996). In short, pigment extraction was carried out using $10 \mathrm{ml}$ of $95 \%$ buffered methanol (2\% ammonium acetate) for $15 \mathrm{~min}$ at $5^{\circ} \mathrm{C}$, in the dark. The extract was filtered onto Whatman GF/F on a Sweenex system. The apparatus used for pigment analysis consisted of 2 pumps (Altex 110A) driven by a gradient programmer (Altex 420), an injection valve with a $100 \mu l$ loop (Rheodyne 7010), a fluorescence detector (Schoeffel FS 720) and a UV-Vis variable wavelength detector (Beckman 165) connected to 3 peak integra- tors (Shimadzu). Chromatographic separation was carried out with a Bio-Sil $C_{18}$ HL 90-5S column for reverse phase chromatography (Biorad, $150 \mathrm{~mm}$ long, $4.6 \mathrm{~mm}$ in diam., $5 \mu \mathrm{m}$ particles). For chloropigments, fluorescence excitation was carried out at $430 \mathrm{~nm}$ (emission beyond $580 \mathrm{~nm}$ ); absorbances (for chlorophylls and carotenoids) were set at 436 and $450 \mathrm{~nm}$. The solvents for the HPLC gradient used were as follows: solvent $\mathrm{A}$ was $0.2 \mathrm{M}$ ammonium acetate in methanol and water $(80: 20, \mathrm{v} / \mathrm{v})$; solvent $\mathrm{B}$ was methanol and ethyl acetate $(70: 30, \mathrm{v} / \mathrm{v})$. The flow rate was $1 \mathrm{ml} \mathrm{min}^{-1}$ and the gradient was linear. The program utilized was $34 \mathrm{~min}$ long. It started with $0 \%$ solvent $B(100 \%$ solvent $A)$, reached $100 \%$ solvent $B$ in $20 \mathrm{~min}$, stayed with $100 \%$ of solvent $\mathrm{B}$ for $7 \mathrm{~min}$ and returned to original conditions in $7 \mathrm{~min}$.

Twenty pigments were quantified. Concentrations of chl a, chlorophyllide a, pheophytins a (peaks no. 29 and 31: Table 2), pheophorbides a (peaks no. 3, 5, 6, 9 , 13 and 15; Table 2), chl $b$, chls $c_{1}+c_{2}$, fucoxanthin and $\beta$-carotene are expressed in $\mu \mathrm{g} \mathrm{g}^{-1}$ of dry sediment, whereas several carotenoids (as respective standards were not available to us) are presented in peak area unit (PAU) per dry weight, namely: alloxanthin, diadinoxanthin, diatoxanthin, lutein, neofucoxanthin, violaxanthin and zeaxanthin.

Microscopic observations. Benthic microalgae are known to migrate vertically in response to a light stimulus. The fraction of the motile population was measured by the lens tissue method (Eaton \& Moss 1966). Pieces of $2 \times 2 \mathrm{~cm}$ of lens tissue were spread on the top of sediment cores and left undisturbed for $24 \mathrm{~h}$. The sediment surface was illuminated artificially for $2 \mathrm{~h}$ before collection of lens tissues which were immediately put in $1.00 \mathrm{ml}$ solution of acidic Lugol. A $10 \mathrm{ml}$ 
Table 2. Identification of peaks from chromatograms of methanol extracts of sediment samples from the Tagus Estuary. Detection by fluorescence (excitation at $430 \mathrm{~nm}$ ) and absorbance at 436 and $450 \mathrm{~nm}$ (n.r.: not identified)

\begin{tabular}{|lc|}
\hline Pigments & Peak no. \\
\hline Solvent front & 0 \\
Chlorophyllide $a$ & 1 \\
Chlorophylls $c_{1}+c_{2}$ & 2 \\
Pheophorbide $a$ & 3 \\
Fucoxanthin & 4 \\
Pheophorbide a & 5 \\
Pheophorbide a & 6 \\
Neoxanthin & 7 \\
Carotenoid n.i. & 8 \\
Pheophorbide a & 9 \\
Violaxanthin & 10 \\
Pheoporphyrin $c_{2}$ & 11 \\
Diadinoxanthin & 12 \\
Pheophorbide $a$ & 13 \\
Neofucoxanthin & 14 \\
Pheophorbides $a$ & 15 \\
Alloxanthin & 16 \\
Diatoxanthin & 17 \\
Carotenoid n.i. & 18 \\
Lutein & 19 \\
Zeaxanthin & 20 \\
n.i. peaks & 21 \\
Chlorophyll $b$ allomers & 22 \\
Chlorophyll $b$ & 23 \\
Chlorophyll a allomers & 24 \\
Chlorophyll $a$ main allomer & 25 \\
Chlorophyll $a$ & 26 \\
Chlorophyll $a$ epimer & 27 \\
Pheophytins $b$ & 28 \\
Pheophytin $a$ & 29 \\
B-Carotene & 30 \\
Pheophytin $a$ & 31 \\
B-Carotene & 32 \\
Phytol chl $c$ & 33 \\
& \\
& \\
&
\end{tabular}

aliquot of this solution was used to identify and count cells in sedimentation chambers in a Wild inverted microscope. A total of 100 to 400 cells were counted (Frontier 1972, Venrick 1978), which enabled us to determine the relative abundance of dominant taxa. Diatoms were identified after cleaning the cells with $30 \%$ hydrogen peroxide. A definitive preparation was made by mounting them in resin (Hyrax). Observations and photography were carried out using an Olympus (BX 50) microscope at 400x and 1000x.

\section{RESULTS}

\section{Qualitative pigment composition}

During the spatial and temporal surveys, a total of 40 peaks were detected, from which 29 pigments were identified, including 14 chlorophyll derivatives. As an example, 4 chromatograms obtained from the salt marsh site sediment (1B), during 3 seasons, are presented in Fig. 2. Fluorescence detection. (Fig. 2A) allowed the separation of chloropigments, namely chl $a$ and allomers, chlorophyllide $a$, pheophorbides $a$ (9 peaks), pheophytins a (2 peaks), chl $b$, pheophytins $b$ (2 peaks), chls $c_{1}+c_{2}$, pheoporphyrin $c_{2}$ (Table 2). Fluorescence detection is particularly useful for sediment sample analysis because some chlorophyll breakdown products co-elute or interfere with carotenoids. Since the latter are not fluorescent, absorbance detection makes it possible to highlight the carotenoids (Fig, 2B, C, D, Table 2). Then chloropigments may be distinguished from carotenoid ones, by comparing Fig. 2A \& B. For example, peaks no. 11, 13, and the group 15 (4 peaks) in Fig. 2A correspond to pheophorbides which co-elute partly with carotenoids no. 10,12 and 14 (violaxanthin, diadinoxanthin, neofucoxanthin).

The chromatograms B, C, and D (Fig. 2) concern 3 dates (25 September 1991, 6 November 1991 and 19 February 1992) and seasonal changes of qualitative composition in the carotenoid stock are obvious. Table 3 links the pigments identified in the Tagus samples to microalgal groups or macrophyte debris, generally observed in our intertidal surface sediments. The following pigments were taken as diagnostic markers ('fingerprints') for taxonomic microalgal groups and macrophytic detrital material: fucoxanthin for diatoms (bacillariophytes), chl b for euglenophytes, chlorophytes and/or phanerogam debris, lutein for chlorophytes and/or phanerogam debris, zeaxanthin for cyanobacteria and alloxanthin for cryptophytes. But, it should be pointed out that the presence of one isolated pigment is not enough to identify an algal group; rather, a certain set of pigments is needed (Table 3). For example, for diatoms, fucoxanthin appears associated with chls $C_{1}+c_{2}$ and in diverse proportions with diadinoxanthin, diatoxanthin and neofucoxanthin. Thus, we observed in September (Fig 2B) and February (Fig, 2D) the simultaneous importance of chls $c_{1}+c_{2}$ (peak 2), fucoxanthin (peak 4), neofucoxanthin (peak 14), characteristic pigments of diatoms, whereas in November, the detection of a prominent diadinoxanthin peak (no. 12) and zeaxanthin peak (no. 20) indicates the presence of euglenophytes and cyanobacteria, respectively. This was ascertained by microscopic observations. A combination of chl $b$, violaxanthin, neoxanthin and lutein is associated with the chlorophytes, but the particular abundance of lutein will indicate the accumulation of plant detritus in the vicinity of the halophyte community. During our study, microchlorophytes were rarely observed. Dinophytes were not counted, nor was their characteristic pigment, peridinin. 

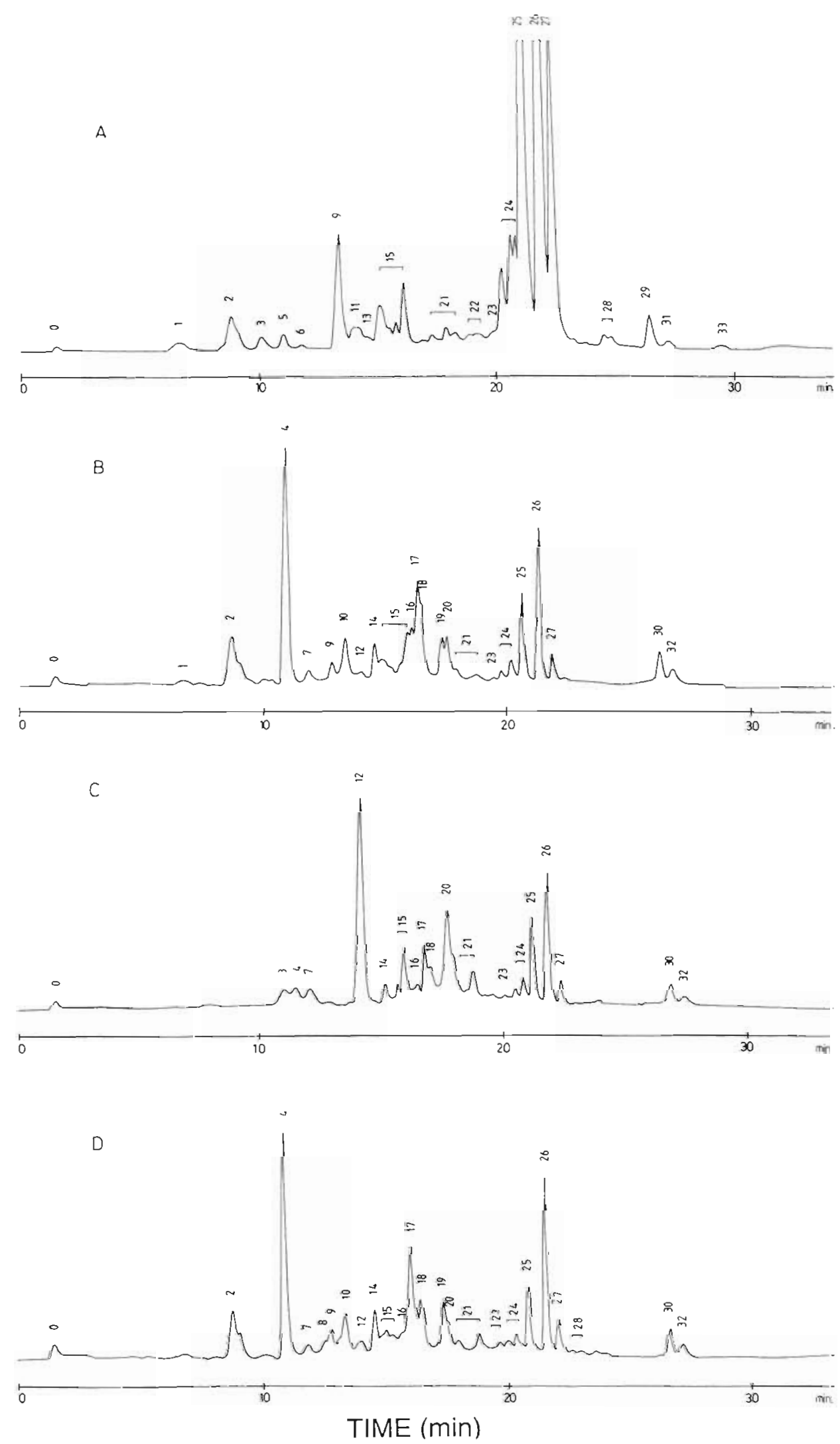

Fig. 2. Chromatograms of the (A) fluorescence and (B, C, D) absorbance at $450 \mathrm{~nm}$ obtained from site $1 \mathrm{~B}$ (salt marsh mud) in the Tagus Estuary. (A, B) 25 September 1991 (sample dry weight: 0.7 g). (C) 6 November 1991 (0.6 g), (D) 19 February 1992 (0.4 g) 
Table 3. Distribution of pigments identified among microphytobenthic algal groups or macrophytic debris in Tagus Estuary intertidal surface sediments. H: high concentration; L: low concentration (after Rowan 1989)

\begin{tabular}{|c|c|c|c|}
\hline \multicolumn{3}{|l|}{$\begin{array}{l}\text { Pigment } \\
\text { Algal type, material or process }\end{array}$} & Source \\
\hline \multicolumn{4}{|c|}{ Chlorophylls and their breakdown products } \\
\hline Chlorophyll a & $\begin{array}{l}\text { Cyanobacteria, bacillariophytes, euglenophyte } \\
\text { chlorophytes, cryptophytes, macrophytic debris }\end{array}$ & & $1,2,3,4$ \\
\hline Chlorophyllide a & Chlorophyllase containing cells, senescent cells & & 4,5 \\
\hline Pheophytins a & Microbial degradation process & & 6 \\
\hline Pheophorbides a & Plant detritic material, grazed material & & 7.8 \\
\hline Pheophorbide a (peak no. 9) & Grazed material, fecal pellets & & 9,10 \\
\hline Chlorophyll $b$ & Euglenophytes, chlorophytes, phanerogam deb & & $1,2,3,4$ \\
\hline Pheophytins $b$ & Detrital material from eugl., chloro., phaneroga & & 6 \\
\hline Chlorophylls $c_{1}+c_{2}$ & Bacillariophytes & & $1,2,3,11$ \\
\hline Chlorophyll $c_{2}$ & Cryptophytes & & 1,11 \\
\hline Pheoporphyrin $c_{2}$ & Detrital bacillariophytes (grazing), phaeophyte & & 10 \\
\hline \multicolumn{4}{|l|}{ Carotenoids } \\
\hline Alloxanthin & Cryptophytes $(\mathrm{H})$ & & $1,2,12,13,14,15$ \\
\hline$\beta$-Carotene & $\begin{array}{l}\text { Cyanobacteria }(H) \text {, bacillariophytes }(H) \\
\text { euglenophytes }(L) \text {, chlorophytes }(H) \text {, macrophy }\end{array}$ & bris & $1,2,15,16,17,18$ \\
\hline Diadinoxanthin & Euglenophytes $(\mathrm{H})$, bacillariophytes $(\mathrm{H})$ & & $2,12,15,18$ \\
\hline Diatoxanthin & $\begin{array}{l}\text { Euglenophytes }(\mathrm{H}) \text {, bacillariophytes, phaeophy } \\
\text { (occasional occurrence) }\end{array}$ & bris & $2,12,15,18$ \\
\hline Fucoxanthin & Bacillariophytes $(\mathrm{H})$, phaeophyte debris & & $2,3,4,12,15,16$ \\
\hline Lutein & Chlorophytes $(\mathrm{H})$, phanerogam debris & & $1,2,3,4,15,16,18$ \\
\hline Neofucoxanthin & Bacillariophytes foccasional occurrences, i.e. C. & rotheca closterium) & $4,18,19$ \\
\hline Neoxanthin & $\begin{array}{l}\text { Cyanobacteria (L), euglenophytes (L), chloroph } \\
\text { bacillariophytes (traces amount), phanerogam }\end{array}$ & & 2,15 \\
\hline Violaxanthin & Bacillariophytes (L), chlorophytes (L), phaeophy & ebris & $2,4,12,16,18$ \\
\hline Zeaxanthin & Cyanobacteria $(\mathrm{H})$, chlorophytes $(\mathrm{L})$, phaneroga & ebris & $1,2,15,16,17,20$ \\
\hline 1, Cohen (1986) & 8, Bianchi et al. (1988) & 15, Bianchi et al. (1 & $33 b)$ \\
\hline 2, Rowan (1989) & 9. Vernet \& Lorenzen (1987) & 16, Abele-Oeschge & $(1991)$ \\
\hline 3, Wright et al. (1991) & 10. Plante-Cuny et al. (1993) & 17, Villanueva et al & (1994) \\
\hline 4, Levinton \& McCartney (1991) & 11, Jeffrey $(1989)$ & 18, Klein \& Riaux-C & bin (1991) \\
\hline 5. Jeffrey (1974) & 12, Bjornland \& Liaaen-Jensen (1989) & 19. Stauber \& Jeffr & (1988) \\
\hline 6. Bianchi et al. (1991) & 13. Pennington et al. $(1985\}$ & 20, Gieskes et al. (1 & \\
\hline 7. Downs (1989) & 14, Gieskes \& Kraay (1983) & & \\
\hline
\end{tabular}

\section{Quantitative pigment analysis}

Spatial variations

Data from chl a values and the ratio of 'total pheopigments $a^{\prime}$ (pheophytıns $a+$ pheophorbicies $a+$ chlorophyllide a) to total chl a + pheopigments a (pheos al chl $a+$ pheos $a$ ) of the 16 sites (10 stations) are given in Fig $3 \mathrm{~A}$. The chl a values ranged from 4 to $38 \mu \mathrm{g} \mathrm{g}^{-1}$ of dry sediment, while total pheopigments a ranged from 3 to $81 \mathrm{\mu g} \mathrm{g}^{-1}$. The percentage of pheopigments was generally greater in salt marshes and low tidal mud flats than in sandier sites. Fig. 3B, C \& D also shows chl $b$, chls $c_{1}+c_{2}$ and fucoxanthin values obtained at the same sites. Highest values for $c h l b$ were observed at sites $1 \mathrm{~A}, 1 \mathrm{~B}$ (salt marsh mud flats), and $3 \mathrm{C}$ (mud flat). Chl $b$ was not detected at sites $6 \mathrm{~A}$ and $6 \mathrm{~B}$ (sand). According to the literature (Table 3 ), chl $b$ might origi- nate both from phanerogam debris or some benthic microalgae. In our case, and according to our microscopic observations, chl $b$ concentration at sites $1 \mathrm{~A}$ and 3A was mainly due to Spartina debris, whereas at the 3 other sites, it seems to have originated mainly from cuglenophytes, as microscopic chlorophytes were seldom seen. The general patterns of chls $C_{1}+C_{2}$ and fucoxanthin were similar, and differed from that of chl $b$. Chls $c_{1}+c_{2}$ exhibited high values at sandy sites $(14,3 \mathrm{~A}, 3 \mathrm{~B}, 6 \mathrm{~A})$, indicating the presence of diatoms. High concentrations of fucoxanthin were observed at sites exhibiting the highest chl a values (e.g. 12A and 3C). Stn 3 (sites $A, B$ and C) was simultaneously rich in chl $b$, chls $c_{1}+c_{2}$ and fucoxanthin, suggesting a highly diverse taxonomic composition.

A linear correlation study among 7 pigments (Table 4) shows that chl a concentrations were positively and significantly correlated with chls $c_{1}+c_{2}$, fucoxanthin, 

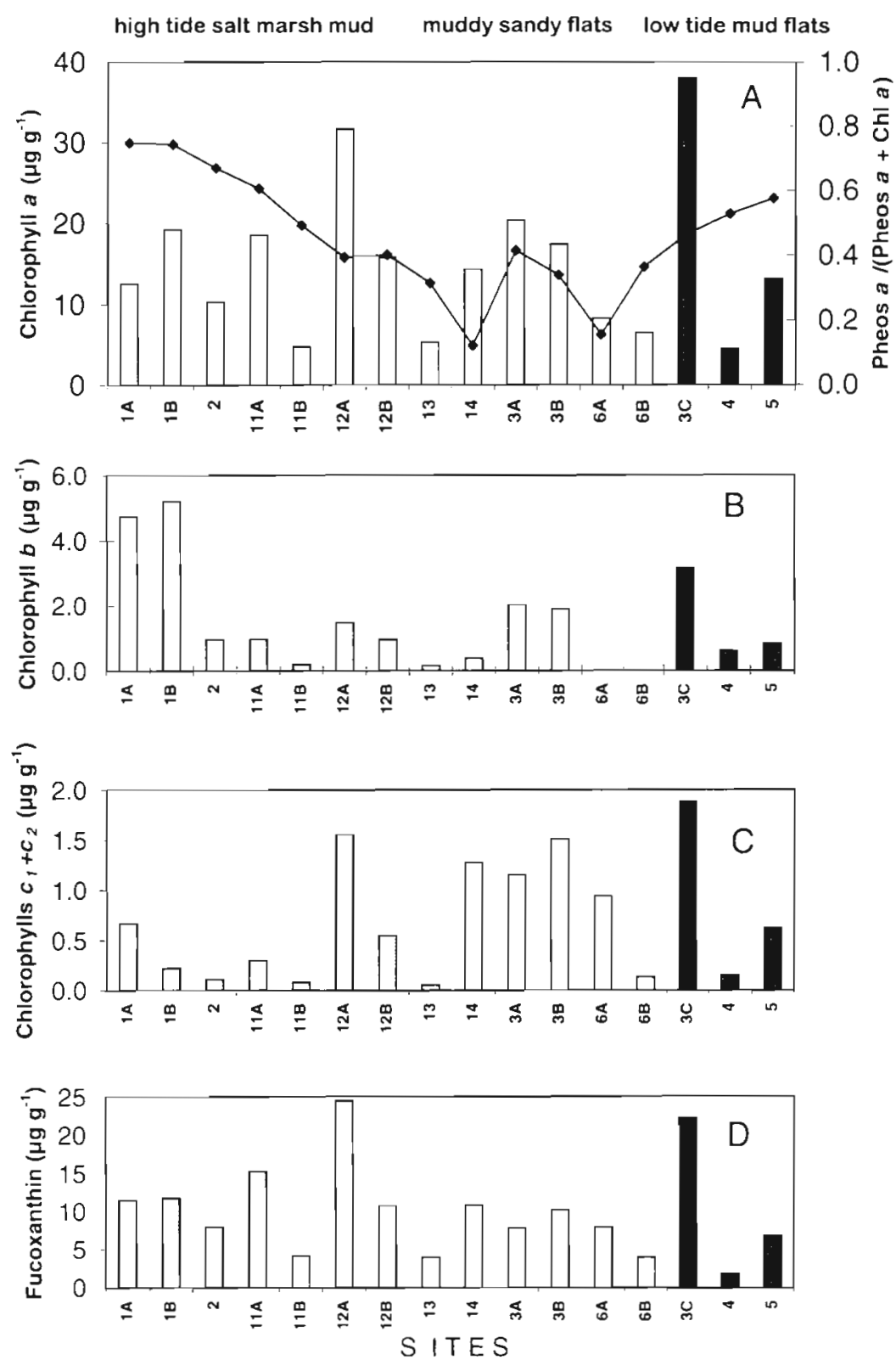

Fig. 3. Spatial variations of the concentrations of (A) chl a (bars) and 'total pheopigments a/chl a + total pheopigments $a^{\prime}$ ratio (solid line), (B) chl $b$, (C) chls $c_{1}+c_{2}$ and (D) fucoxanthin in the top $5 \mathrm{~mm}$ of sediment sampled at 16 sites in spring 1990 and neofucoxanthin. These results indicate that diatoms constitute the major contributing group to the total chl a pool. The very high positive correlation between chl $b$ and diatoxanthin ( $r=$ 0.92) suggests that the main source of diatoxanthin is euglenophyte cells.

\section{Temporal variations}

Seasonal variations in pigment concentration were studied at sites $1 B$ (salt marsh mud), 3B (mid shore sand flat) and $3 \mathrm{C}$ (low tide mud flat).

Chl a and breakdown products. Chl a values varied seasonally from 3 to $98 \mu \mathrm{g}$ $\mathrm{g}^{-1}$, considering data from all sites (Fig. 4). Chlorophyllide $a$ and pheophytins a concentrations were almast negligible compared to chl a values. In contrast, pheophorbides a values were 2 to 4 times higher than chl a values. On average, pheophorbides a represented $90 \%$ of total pheopigments $a$. On the whole, chl a concentrations were 4 -fold and pheophorbides a 5- to 7 -fold higher at muddy sites ( $1 B$ and $3 C$ ) than at the sandy site (3B).

At the salt marsh site $1 B$, annual mean values of chl $a$ and pheophorbides $a$ were 52 and $118 \mu \mathrm{g} \mathrm{g}^{-1}$, respectively. In summer, autumn and late winter, chl a peaks were accompanied by pheophorbide increases, suggesting an accumulation of detrital material from autochthonous chl a. At the sandy site $3 \mathrm{~B}$, the distribution of chl a was uniform throughout the year (annual mean value of $14 \mu \mathrm{g} \mathrm{chl} \mathrm{a} \mathrm{g}^{-1}$ ), while pheophorbides a increased slightly in autumn and early spring (annual mean $=24 \mu g^{-1}$ ). In contrast to the muddy sites $(1 \mathrm{~B}, 3 \mathrm{C})$,

Table 4. Linear correlation between pigment concentration for the 16 sites studied during spring 1990 . Significance: $p<0.05$, $\cdot p<0.001$

\begin{tabular}{|c|c|c|c|c|c|c|}
\hline & Chl a & Chl $b$ & Chis $c_{1}+c_{2}$ & $\beta$-Carotene & Diatoxanthin & Fucoxanthin \\
\hline Chl a & - & & & & & \\
\hline Chl $b$ & 0.49 & - & & & & \\
\hline Chls $C_{1}+c_{2}$ & $0.77^{\cdots}$ & 0.23 & - & & & \\
\hline$\beta$-Carotene & 0.48 & 0.45 & $0.62^{\circ}$ & - & & \\
\hline Diatoxanthin & 0.39 & $0.92 \cdots$ & 0.11 & 0.33 & - & \\
\hline Fucoxanthin & $0.92 \cdots$ & 0.43 & $0.69^{\circ}$ & 0.25 & 0.36 & - \\
\hline Neofucoxanthin & $0.89 \cdots$ & 0.21 & $0.74^{\circ}$ & 0.21 & 0.19 & $0.95 \cdots$ \\
\hline
\end{tabular}



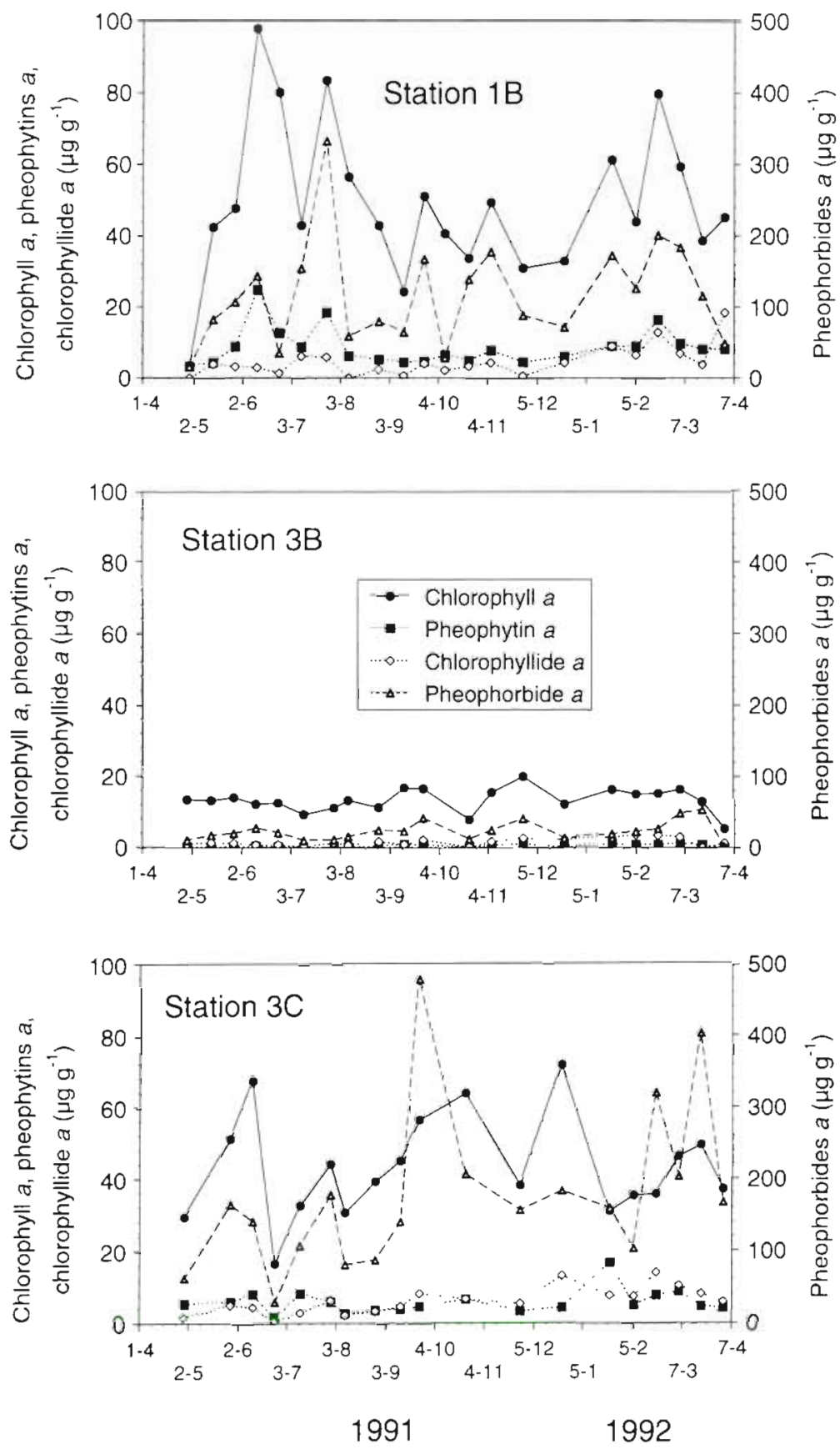

Fig. 4. Temporal variations of the concentrations of chlorophyll pigments (chl $a+$ chlorophyllide $a+$ pheophytins $a_{1}$ left $y$-axis; and pheophorbides $a_{1}$ right $y$-axis) during 12 mo (1991-1992) at sites $1 B, 3 B$ and $3 C$. $x$-axis units represent day-month

there was also an extremely low concentration of pheophytin a (annual mean $=0.6 \mu \mathrm{g} \mathrm{g}^{-1}$ ), lower than chlorophyllide a concentration (annual mean $=1.8 \mu \mathrm{g}$ $\left.\mathrm{g}^{-1}\right)$. At site $3 \mathrm{C}$, seasonal variations in chl $a$ and pheopigments a seemed to vary independently of one another, particularly from September onward. Annual mean values of chl $a$ and pheophorbides a were respectively 44 and $179 \mu \mathrm{g} \mathrm{g}^{-1}$. Interestingly, pheophorbides reached high values $\left(>400 \mu \mathrm{g} \mathrm{g}^{-1}\right)$ in 2 distinct periods, September and March. On the whole, seasonal chl a maxima were seen in June, July and late winter in site $1 \mathrm{~B}$, whilst at site $3 \mathrm{C}$. during June and again in December. No peak occurred at site $3 \mathrm{~B}$

Biomarker pigments. The seasonal variations of 5 'fingerprints' for sites $1 \mathrm{~B}$ (salt marsh mud) and $3 C$ (low tide mud flat) from April 1991 to April 1992 are presented in Fig. 5. As far as site 3B (muddy sandy tidal flat) is concerned, only fucoxanthin and chl $b$ are shown, as the other diagnostic pigments were present in very low concentrations (Fig. 6).

At the salt marsh site $(1 \mathrm{~B})$, high values of fucoxanthin (annual mean $32 \mu \mathrm{g} \mathrm{g}^{-1}$ ) matched with the abundance of diatom cells (Fig. 7A, B, C, J \& K shows some characteristic diatom species from this site). Relatively high levels of chl $b$ (annual mean $9.6 \mathrm{\mu g} \mathrm{g}^{-1}$ ) were due to the abundance of halophyte detritus and euglenophytes, particularly Euglena acusformis Schiller (Fig. 7E). As chlorophytes were rarely observed, the high lutein concentration indicates that a significant part of $\operatorname{chl} b$ could originate from plant detritus. June, July, October and February lutein peaks colncided with those of pheophorbides a (Fig. 4, site 1B), attesting to the degradation process of autochthonous vegetation. Zeaxanthin concentrations were sometimes nondetectable (Fig. 5) but sometimes high (for example Fig. 2C, 6 November 1991. peak no. 20), corresponding then to populations of cyanobacteria filaments (Fig. 7H). Distinct peaks of alloxanthin appeared in 1991-92 (Fig. 5 and also Fig. 2B, 25 September 1991, peak no. 16) but cryptophyte cells, the usual source of alloxanthin, were not observed in sediment samples. In short, in summer and spring, chl a peaks (Fig. 5, dotted line) correspond to the presence of diatoms and plant debris as evidenced by fucoxanthin and lutein peaks. Diatom populations decreased sharply in November, when they were temporarily replaced by cyanobacteria (zeaxanthin peak). These in turn virtually disappeared from 5 February onward.

At the low tide mud flat site (3C), the fucoxanthin and chl a seasonal patterns were similar (Fig. 5). The diatom populations was noticeably less abundant in 

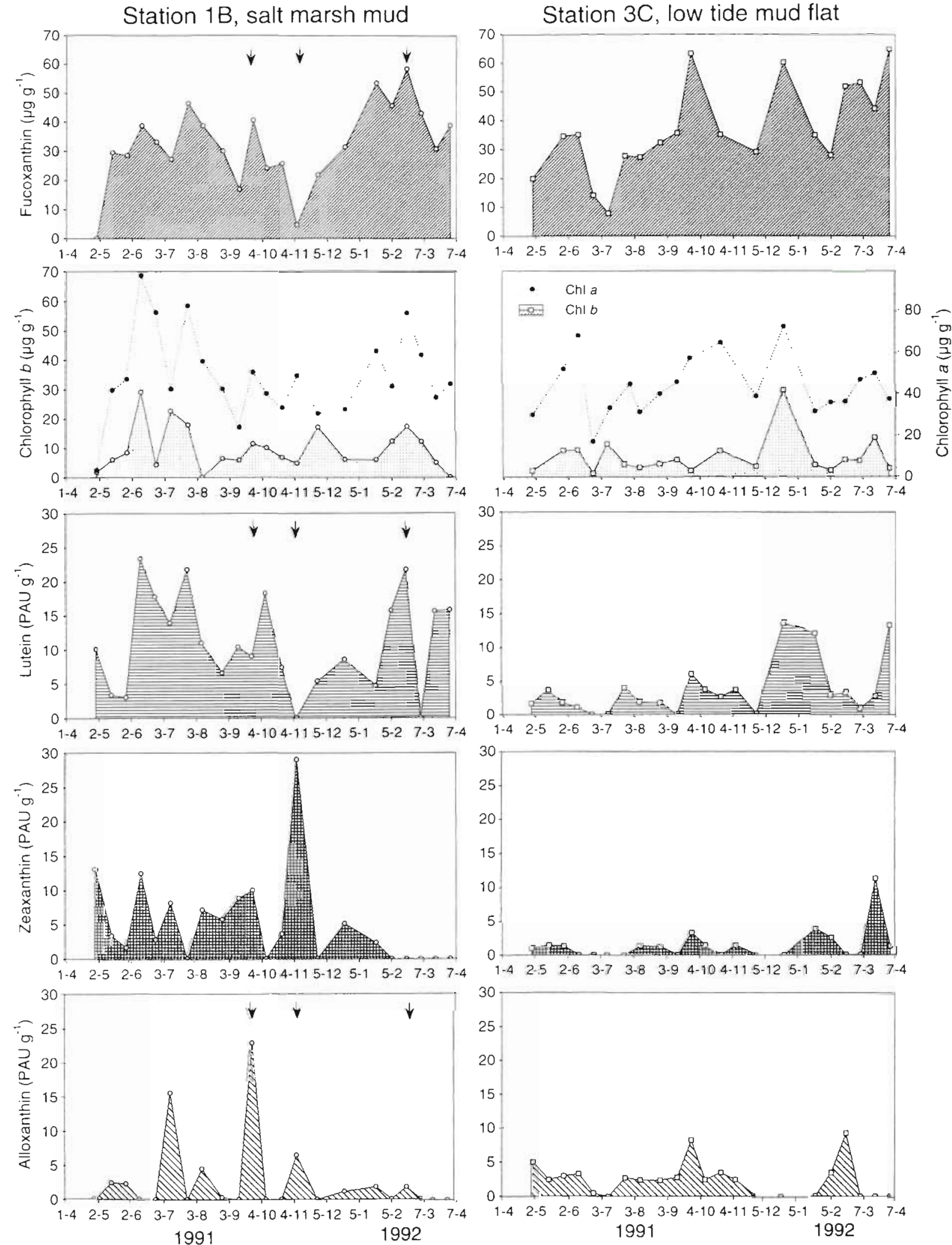

Fig. 5. Pigment marker concentrations in the sediment surface $(0$ to $5 \mathrm{~mm}$ ) of sites $1 \mathrm{~B}$ (high tide salt marsh mud) and $3 \mathrm{C}$ (low tide mud flat) between April 1991 and April 1992. Dotted line: chl a concentration. Arrows indicate sampling dates corresponding to Fig. 2 chromatograms. PAU: peak area units 


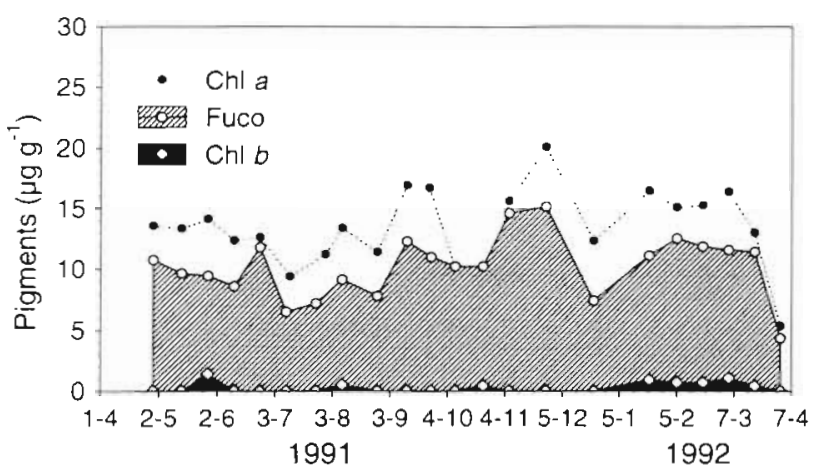

Fig. 6. Seasonal variations in the concentration of chl $a$, chl $b$ and fucoxanthin in the sediments at site 3B (mid-shore sandy flat). The concentrations of lutein, zeaxanthin and alloxanthin were very low

summer than during the rest of the year. Typical mud flat diatom species are shown in Fig. $7 \mathrm{~A}, \mathrm{C}, \mathrm{D} \& \mathrm{G}$. Chl $b$ concentration (annual mean of $5 \mu \mathrm{g} \mathrm{g}^{-1}$ ), although lower than at site $1 \mathrm{~B}$, was still relatively high. However, lutein was much less abundant, which suggests that euglenophytes were here the important source of chl $b$, particularly in December, when they contributed to the chl a peak. Zeaxanthin concentration, which matched the observation of a small cyanobacteria species, was also less abundant than at site $1 \mathrm{~B}$, although it presented a peak in March. Alloxanthin was observed throughout the year, but did not display such abrupt peaks as at site $1 \mathrm{~B}$.

At the sandy site $3 \mathrm{~B}$ (Fig. 6), fucoxanthin concentration (annual mean of $10 \mu \mathrm{g} \mathrm{g}^{-1}$ ), as well as that of chl a (Fig. 4), remained fairly constant throughout the year, except for a slight increase in winter. Diatoms dominated the microphytic population (95 to $99 \%$ of ail cells), and Cylindrotheca closterium (Ehrenb.) Reimer \& Lewin (Fig. 7I) was the dominant species. Chl $b$ was merely present and may be related to the presence of some euglenophytes and filamentous chlorophytes.

Considering data from the 3 sites, diatom microscopic counts (motile cells only) were positively correlated with fucoxanthin concentration $(r=0.53, n=48$, $p<0.001$ ). For euglenophytes and cyanobacterid, the number of individuals counted was relatively low; there was thus no significant relationship with the diagnostic pigment results, although species observations corresponded to pigment concentrations.

Diatoms dominated at the 3 sites examined. Cylindrotheca closterium (Fig. 7I) and Navicula cryptocephala Kützing (Fig. 7J) were the dominant species. Euglenophytes were observed at all sites, but more rarely at the mid-shore sandy flat site (3B), and cyanobacteria were much more conspicuous in the salt marsh mud site 1B. Microchlorophyte cells were also observed, but more rarely.
Table 5. Linear correlation between chlorophyll a and fucoxanthin concentrations and the other pigments recorded during the seasonal survey at sites $1 \mathrm{~B}$ and $3 \mathrm{C}$. Signuficance: $\cdot p<0.05, \cdots p<0.001$

\begin{tabular}{|c|c|c|c|c|}
\hline \multirow[b]{2}{*}{ Chlorophyllide a } & \multicolumn{2}{|c|}{$\begin{array}{c}\text { Site } 1 \mathrm{~B} \\
\text { salt marsh mud } \\
\text { Chl a Fucoxanthin }\end{array}$} & \multicolumn{2}{|c|}{$\begin{array}{c}\text { Site } 3 C_{1} \\
\text { low tide mud flat } \\
\text { Chl a Fucoxanthin }\end{array}$} \\
\hline & 0.18 & $0.56^{\circ}$ & 0.17 & 0.21 \\
\hline Pheophytin $a$ & $0.92 \cdots$ & $0.51^{\circ}$ & 0.05 & 0.03 \\
\hline Chl $b$ & $0.60^{\circ}$ & 0.30 & $0.65^{\circ}$ & 0.28 \\
\hline Chls $c_{1}+c_{2}$ & $0.43^{\circ}$ & $0.60^{\circ}$ & 0.18 & 0.35 \\
\hline Alloxanthin & -0.04 & 0.02 & 0.10 & 0.19 \\
\hline$\beta$-Carotene & $0.90^{\prime}$ & 0.36 & -0.03 & $0.54^{\circ}$ \\
\hline Diadinoxanthin & 0.12 & -0.38 & 0.09 & 0.39 \\
\hline Diatoxanthin & 0.19 & 0.40 & 0.16 & $0.59^{\circ}$ \\
\hline Fucoxanthin & $0.56^{\circ}$ & - & $0.52^{\circ}$ & - \\
\hline Lutein & $0.48^{\circ}$ & 0.31 & 0.22 & $0.62^{\circ}$ \\
\hline Neofucoxanthin & $0.79 \cdots$ & $0.79 \cdot$ & 0.25 & $0.71 \cdots$ \\
\hline Violaxanthin & $0.62^{\circ}$ & 0.19 & 0.25 & $0.50^{\circ}$ \\
\hline Zeaxanthin & 0.00 & $-0.52^{\circ}$ & 0.02 & 0.18 \\
\hline
\end{tabular}

Examination of the linear correlation matrix among 14 pigment concentrations (Table 5) gives rise to several remarks. At site $1 B_{1}$ positive and significant correlations between chl $a$ and chls $c_{1}+c_{2}$, fucoxanthin, and neofucoxanthin, as well as between fucoxanthin and chls $c_{1}+c_{2}$ and especially neofucoxanthin, were observed. Chl a is also well correlated with chl $b$, $\beta$-carotene, lutein and violaxanthin, showing the importance of plant debris at this salt marsh muddy site. The negative correlation between fucoxanthin and zeaxanthin ( $\mathrm{r}=-0.52$ ) confirms that diatom and cyanobacteria populations seem to succeed one another in time. At site $3 \mathrm{C}$ (mud flat), chl a was correlated with fucoxanthin and chl $b$ only. This supports the hypothesis that diatoms and euglenophytes contribute most, and together, to the chl a pool. Fucoxanthin was related to neofucoxanthin, diatoxanthin (which is common both in diatoms and euglenophytes) and to violaxanthin, lutein and $\beta$-carotene, which could indicate the presence of macrophyte debris (Table 3 ). In the vicinity of sites $3 \mathrm{~B}$ and $3 \mathrm{C}$ there are populations of Fucus vesiculosus (phaeophyte), which might contribute to the carotenoid pool.

\section{DISCUSSION}

\section{Pigment signatures, biomarkers}

In the benthic field, studies using pigments to determine the origin of organic matter are more frequent than those analysing microphytobenthos communities from a taxonomic standpoint. Papers dealing with live microphytic populations have been rare, due to the 

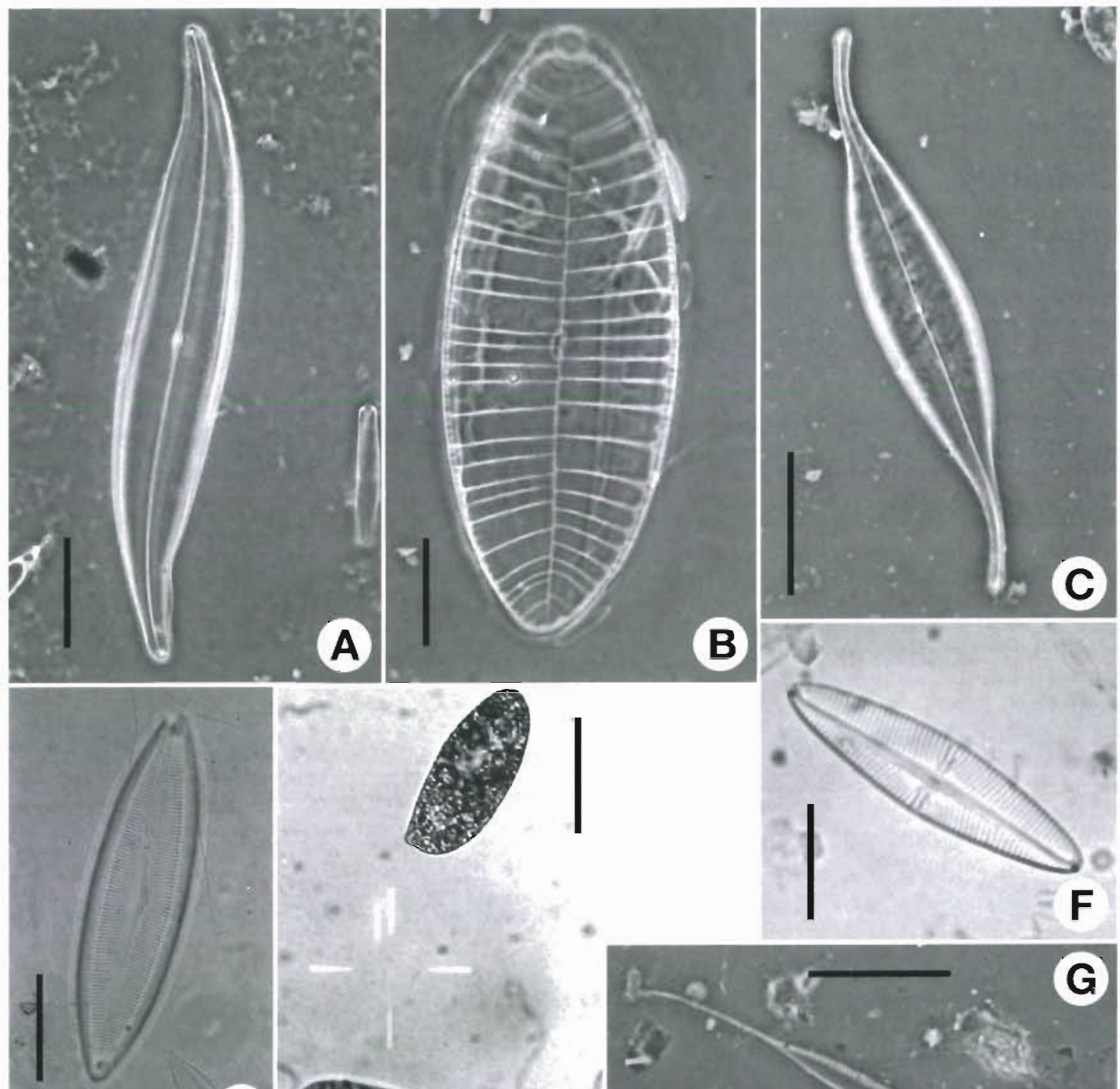

B
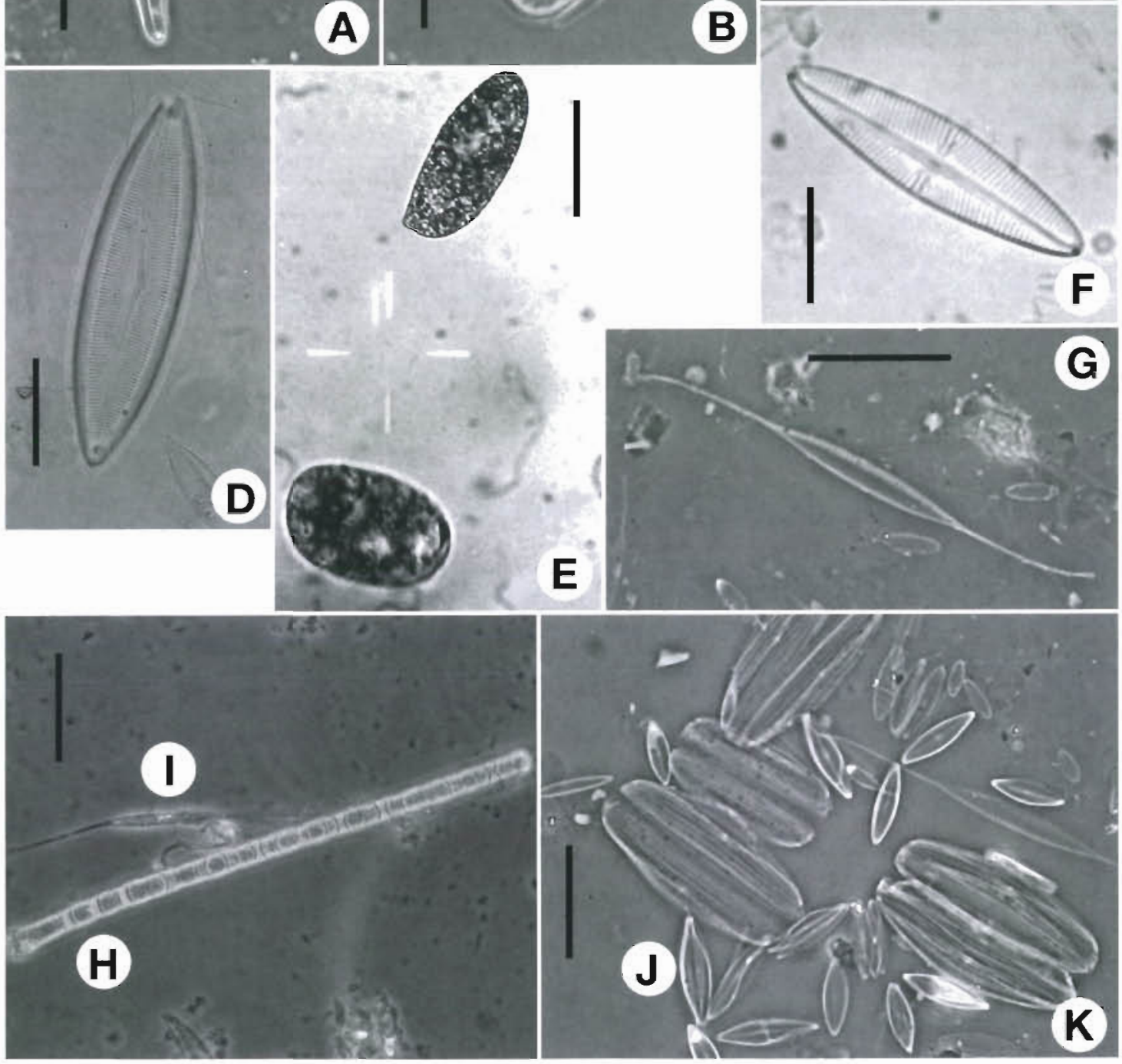

Fig. 7. Microphytic species observed on the different type of sediments. Diatoms (bacillariophytes): (A) Gyrosigma acuminatum Grün., (B) Surirella gemma (Ehrenb.) Kützing, (C) Gvrosigma fasciola (Ehrenb.) Cleve, (D) (aloneis westii (Wm. Smith) Hendey. (F) Navicula digito-radiata (Gregory) Ralfs, (Ci) Nitzschia longissima (Brébisson) Ralfs, (I) Cylindrotheca closterium (Ehrenb.) Reimer, (J) Navicula cryptocephala Kützing. (K) Amphora hyalina Kützing. Euglenophyte: (E) Euglena acusformis Schiller 
complexity prevailing in the sediment surface, where pigments from several taxonomic groups of microalgae are in a pool with degraded chlorophylls and carotenoids originating from senescent cells, macroalgae and phanerogams

In the present work, both pigment results and microscopic observations testified that diatoms are the major taxonomic group present at all sites and almost throughout the year. Most authors, in various sediment types, found the same results, i.e. high concentration of fucoxanthin and chls $c_{1}+c_{2}$, corresponding to the dominance of diatom populations (Riaux-Gobin et al. 1987, Abele-Oeschger \& Schramm 1989, Levinton \& McCartney 1991, Bianchi et al. 1993b, Barranguet \& Alliot 1995, Cariou-LeGall \& Blanchard 1995, Barranguet et al. 1996). Moreover, Klein \& Riaux-Gobin (1991), in coastal sediments from sub-antarctic islands. linked the microscopic observation of diatoms with the detection of 'chl $c$ ', fucoxanthin, neofucoxanthin, diadinoxanthin, diatoxanthin and $\beta$-carotene, as we have. We have reported the importance of neofucoxanthin in our samples. This xanthophyll pigment is particularly found in cultures of the diatom Cylindrotheca closterium (Stauber \& Jeffrey 1988). Accordingly, C closterium is a very abundant species in all our samples, often the dominant one.

In the spatial survey, the ratio chl a:fucoxanthin varied between 1 and $2.6(\mathrm{~g} / \mathrm{g})$; the highest value was obtained in a sandy site under a Spartina canopy (site 3A), where an important chl a source is the phanerogam debris. The mean values from the seasonal study were 1.38 at site $1 \mathrm{~B}, 1.36$ at site $3 \mathrm{~B}$ and 1.26 at site $3 \mathrm{C}$. In a temperate intertidal muddy sediment (west coast of France), Cariou-LeGall \& Blanchard (1995) found a mean value of 2.6. Barranguet et al. (1996) report ratios between 0.72 and 2 in Mediterranean sediments (0.5 to $13 \mathrm{~m}$ depth). Burford et al. (1994) obtained a mean value of 0.35 in an Australian tropical bay ( 0 to $60 \mathrm{~m}$ depth), attributing this low value to the abundance of detritic fucoxanthin. The ratios we obtained in intertidal estuarine sediments can be qualified as low, taking into account that only a part of chl a originates from diatoms. We therefore put forward 2 hypotheses to attempt to explain this fact. The first is the decrease in chl a concentration which occurs together with the increase of carotenoids as photoprotectors under high light intensities. During low tide periods in the Tagus Estuary, the surface sediment is submitted to high light intensities, particularly in spring and summer (Brotas \& Catarino, 1995). The second hypothesis is that part of the fucoxanthin could be the result of digestion of infauna. In fact, AbeleOeschger \& Theede (1991), analyzing the digestion of the gastropod Littorina littorea, confirmed that chl a was degraded into pheophytins a and pheophor- bides $a$, whereas fucoxanthin was digested in negligible quantities.

The range of the ratio chl a:chl $b(\mathrm{~g} / \mathrm{g})$ in the 16 sites varied from 2.6 to 39 ; the minimum values came from the salt marsh site, and the maxima from sandy flats where no euglenophytes or plant debris were present. In fact, the pigment ratio values confirm that sandy stations have a community constituted exclusively of diatoms (see Figs, $1 \& 3$ ), whereas in muddy sites, the taxonomic diversity is higher. A wide range is also reported by Barranguet et al. (1996), who found values between 1.2 to 36.8 in different sites between 0.5 and $13 \mathrm{~m}$.

During the seasonal study, chl $b$ was measured in appreciable quantities (annual mean value of $9.6 \mu \mathrm{g}$ $\mathrm{g}^{-1}$ at site $1 \mathrm{~B}$ and $5 \mu \mathrm{g} \mathrm{g}^{-1}$ at site $3 \mathrm{C}$ ). Klein \& RiauxGobin (1991) measured high concentrations of chl $b$ $\left(6.38 \mu \mathrm{g} \mathrm{g}^{-1}\right)$ and diadinoxanthin $\left(3.54 \mu \mathrm{g} \mathrm{g}^{-1}\right)$, related to euglenoid and/or green aigae populations, whereas Cariou-LeGall \& Blanchard (1995) were unable to detect chl $b$. In most papers dealing with sediment, high concentrations of $c h l b$ and lutein are often linked to the presence of plant debris (Levinton \& McCartney 1991, Barranguet \& Alliot 1995) as well as chl b, lutein and $\beta$-carotene (Abele-Oeschger 1991, Bianchi et al. 1993b). The important peaks of alloxanthin observed in July and September 1991 (site 1B) could originate from ephemeral cryptophyte planktonic blooms. In fact, Cabeçadas (in press) observed blooms of cryptophytes in the water column at this site (up to $80 \%$ of total cells) which appeared and disappeared in 1 wh.

The difficulty in characterizing a microphytic community is increased by the possible presence of nondegraded carotenoids from macrophytes, and the reactions designated as 'xanthophylls cycles' (Stransky \& Hager 1970), where low light intensities promote epoxidation and high intensities stimulate de-epoxidation (Rowan 1989, Demmig-Adams 1990, Young 1991). Thus, as a response to stress by high light intensities, the diadinoxanthin-diatoxanthin equilibrium is shifted towards diatoxanthin (Demers et al. 1991, Brunet et al. 1993, Johnsen et al. 1994), and zeaxanthin is produced from violaxanthin transformation (Demmig-Adams 1990). Hence, high diatoxanthin concentrations may be caused by an excess of light in the Tagus Estuary during low tide. The predominance of diadinoxanthin in the euglenophytes in sediments near sub-antarctic islands where the light exposure may be low (Klein \& Riaux-Gobin 1991) is also in agreement with this hypothesis.

We should point out that previous results of chl a measurements in parallel samples with 6 replicates (Brotas et al. 1995) indicated a mean coefficient of variation of $22 \%$ for sandy sites and $33 \%$ in muddy ones. Therefore analysis of seasonal patterns of Fig. 5 must 
be limited by the assumption of the same order of variability for the various pigments. Brotas et al. (1995) also concluded that there was no definite seasonal pattern. Biomass at the upper littoral muddy site (1B) was more influenced by cyclic climatic parameters (e.g. light intensities higher in spring or summer) whereas at the lower littoral site (3C) a decrease in resuspension (derived from the action of tides) caused an increase in biomass in winter. Present data apparently corroborate this idea. Concerning site $1 \mathrm{~B}$, chl $a$, fucoxanthin, chl $b$ and lutein showed higher values in June, July and early spring. At site $3 \mathrm{C}$, chl a has peaks in June and December, fucoxanthin values are clearly higher in winter than in summer, and chl $b$ and lutein present distinct peaks in December. Regarding sandy site 3B, there is an uniform distribution of pigment content, with a slight increase in winter as well.

\section{Degraded chloropigments}

The interpretation of degraded chloropigments is particularly complex in sediment samples. It is noticeable that we found very low concentrations of degraded chl $b$ and chls $c_{1}+c_{2}$, but found a large number of various pheophorbides a ( 9 peaks of unequal importance; Fig. 2A). Pheophorbides a are considered by several authors as an index of planktonic or benthic grazing activities (Klein \& Sournia 1987, Vernet \& Lorenzen 1987, Bianchi et al. 1988, Abele-Oeschger \& Theede 1991, Bianchi et al. 1991, Plante-Cuny et al. 1993, Buffan-Dubau et al. 1996) whereas pheophytins a are generally linked to microbial activity (Bianchi et al. 1991). Our results consistently showed that the pheophorbide a no. 9 (Fig. 2, Table 2), which is less polar than pheophorbides a no. 3, 5 or 6 and than fucoxanthin, always presented the highest concentrations. It was particularly abundant in SeptemberOctober and in March-April at the low tide mud flat site. This fact could be related to the abundance in that zone of the fish Liza ramada (Almeida et al. 1993), which is known to feed on the surface microfilm sediment, its faeces accumulating in the surface sediment (Odum 1970). Buffan-Dubau et al. (1996) found a similar pheophorbide $a$ in the digestive tract of benthic harpacticoid copepods. In the Mediterranean Sea (France), Plante-Cuny et al. (1993) found the most important pheophorbide a peak (corresponding to no. 9 from the Tagus Estuary) in mussel faeces and under mussel mud extracts, attributing its origin to phytoplankton digestion. In oyster farms, Pastoureaud et al. (1996) found 6 peaks of pheophorbides $a$ in the natural seawater and 8 peaks in the faeces of the oyster Crassostrea gigas. The 2 most important peaks correspond to our peak no. 9 (less polar than the former group). Therefore, chl a appears to be subjected to weaker degradation processes in molluscs and sediment grazing fish than in copepods.

In conclusion, the HPLC analysis of chloropigments and carotenoids associated with the study of convenient pigment ratios and correlations appears a powerful tool to discriminate microphytic communities, both in spatial heterogeneity distribution and temporal succession, although controls by microscopic observations are still needed, as demonstrated for phytoplankton communities by Roy et al. (1996). Further studies of the various pheophorbides from chl a are apparently a promising way to distinguish the origin of organic matter degraded by the various functional groups of grazers.

Acknowledgements. We are grateful to Prof Edwin Bourget and Prof. Raphael Plante who offered constructive criticism of this manuscript and to 4 anonymous reviewers for critical comments. This work was financially supported by the LusoFrench co-operation program in Oceanology (JNICT and French MAE, CNRS/INSU/IFREMER), by the project STRDA/ MAR/239/92 (JNICT), by the European Union ELOISE program, under the framework of the NICE project carried out under contract MAS3-CT96-0048, by the Instituto de Oceanografia - Universidade de Lisboa and by the Centre d'Océanologie de Marseille (OSU) - (CNRS/ Université de la Méditerranée, URA 41 and UMR 6540), where HPLC analyses were performed.

\section{LITERATURE CITED}

Abele D (1988) Carotinoide als biogene Marker für benthische Makroalgen im Sediment der Kieler Bucht. Ber Inst Meereskde Univ Kiel 183:1-116

Abele-Oeschger D (1991) Potential of some carotenoids in two recent sediments of Kiel Bight as biogenic indicators of phytodetritus. Mar Ecol Prog Ser 70:83-92

Abele-Oeschger D, Schramm W (1989) Carotenoids as biomarkers for macrophyte derived detrital material in a shallow coastal water ecosystem. In: Ros JD (ed) Topics in marine biology. Scient Mar 53:315-318

Abele-Oeschger D, Szaniawska A, Theede H (1992) Do pigments reflect the turnover of plant material in food chain studies? Analysis of plant pigments in the intestine of Saduria (Mesidotea) entomon. Mar Ecol Prog Ser 81: $43-49$

Abele-Oeschger D, Theede H (1991) Digestion of algal pigments by the common periwinkle Littorina littorea L. (Gastropoda). J Exp Mar Biol Ecol 147:177-184

Almeida PR, Moreira F, Costa JL, Assis CA, Costa MJ (1993) The feeding strategies of Liza ramada (Risso) in fresh and brackish water in the River Tagus, Portugal. J Fish Biol 42:95-107

Andersen RA, Bidigare RR, Keller MD, Latasa M (1996) A comparison of HPLC pigment signatures and electron microscopic observations for oligotrophic waters of the North Atlantic and Pacific Oceans. Deep Sea Res II 43: $517-537$

Barlow RG, Collos Y, Maestrini SY, Roy S (1990) Microphytobenthic pigments in a salt marsh pond determined by HPLC and spectrophotometry. Mar Microb Food Webs $4: 117-128$ 
Barranguet C, Alliot E (1995) Variations spatio-temporelles des flux benthiques (oxygène et ammonium) et de la biomasse microphyto-benthique dans la zone conchylicole de l'étang de Thau (France). J Rech Océanogr 20:15-26

Barranguet C, Plante-Cuny MR, Alivon E (1996) Microphytobenthos production in the Gulf of Fos, French Mediterranean coast. Hydrobiologia 333:181-193

Bianchi TS, Dawson R, Sawangwong P (1988) The effects of macrobenthic deposit-feeding on the degradation of chloropigments in sandy sediments. J Exp Mar Biol Ecol $12: 242-255$

Bianchi TS, Dibb JE, Findlay S (1993a) Early diagenesis of plant pigments in Hudson River sediments. Estuar Coast Shelf Sci 36:517-527

Bianchi TS, Findlay S (1990) Plant pigments as tracers of emergent and submergent macrophytes from the Hudson River. Can J Fish Aquat Sci 47:492-494

Bianchi TS, Findlay S, Dawson R (1993b) Organic matter sources in the water column and sediments of the Hudson River Estuary: the use of plant pigments as tracers. Estuar Coast Shelf Sci 36:359-376

Bianchi TS, Findlay S, Fontvieille D (1991) Fxperimental degradation of plant materials in Hudson River scdiments I. Heterotrophic transformations of plant pigments. Biogeochemistry $12: 171-1.87$

Bjornland T, Liaaen-Jensen S (1989) Distribution patterns of carotenoids in relation to chromophyte phylogeny and systematics. In: Green JG, Leadbeater BSC, Diver WL (eds) The chromophyte algae: problems and perspectives. Systematics Assoc Spec Vol 38, Clarendon Press, Oxford, p $37-60$

Brotas V, Cabrita T, Portugal A, Serodio J, Catarno F (1995) Spatio-temporal distribution of microphytobenthic biomass in tidal flats of the Tagus Estuary (Portugal). Hydrobiologia 300/301:93-104

Brotas V. Catarino F (1995) Microphytobenthos primary production of Tagus Estuary intertidal flats (Portugal). Neth $J$ Aquat Ecol 29:333-339

Brotas V. Plante-Cuny MR (1996) Identification el quantification des pigments chlorophylliens et carotenoides des sédiments marins: un protocole d'analyse par HPLC Oceanol Acta 19:623-6.34

Brunet C, Brylinski JM, Lemoine $Y$ (1993) In situ variations of the xanthophylls diatoxanthin and diadinoxanthin: photoadaptation and relationships with a hydrodynamical system in the eastern English Channel. Mar Ecol Prog Ser 102:69-77

Buffan-Dubau E, de Wit R, Castel J (1996) Feeding selectivity of the harpacticoid copepod Canuella perplexa in benthic muddy environments demonstrated by HPLC analyses of chlorin and carotenoid pigments. Mar Ecol Prog Ser 137: $71-82$

Burford MA, Long BG, Rothlisberg PC (1994) Sedimentary pigments and organic carbon in relation to microalgal and benthic faunal abundance in the Gulf of Carpentaria. Mar Ecol Prog Ser 103:111-117

Cabeçadas L (in press) Phytoplankton production in the Tagus Estuary (Portugal). Oceanol Acta

Canou-Le Gall V, Blanchard GF (1995) Monthly HPLC measurements of pigment concentration from an intertidal muddy sediment of Marennes-Oléron Bay. France. Mar Ecol Prog Ser 121:171-179

Catarino F, Tenhunen JD, Brotas V, Lange OL (1985) Application of $\mathrm{CO}_{2}$-porometer methods to assessment of components of photosynthetic production in estuarine ecosystems. Mar Biol 89:37-43

Cohen $Z$ (1986) Products from microalgae. In: Richmond A (ed) Handbook of microalgal mass culture. CRC Press. Boca Raton, p 421-454

Demers S, Roy S, Gagnon R, Vignault C (1991) Rapid lightinduced changes in cell fluorescence and in xanthophyllcycle pigments of Alexandrium excavatum (Dinophyceae) and Thalassiosira pseudonana (Bacillariophyceae): a photoprotection mechanism. Mar Ecol Prog Ser 76:185-193

Demmig-Adams B (1990) Carotenoids and photoprotection in plants: a role for the xanthophyll zeaxanthin. Biochim Biophys Acta 1020:1-24

Downs JN (1989) Implications of the phaeopigment, carbon and nitrogen content of sinking particles for the origin of export production. PhD thesis, University of Washington

Eaton EJ, Moss B (1966) The estimation of numbers and pigment content in epipelic algal populations. Limnol Oceanogr 11:584-595

Frontier S (1972) Calcul de l'erreur sur un comptage de zooplankton. J Exp Mar Biol Ecol 8:121-132

Gieskes WWC (1991) A.lgal pigment fingerprints: clue to taxon-specific abundance, productivity and degradation of phytoplankton in seas and oceans. In: Demers $S$ (ed) Particle analysis in oceanography. NATO ASI Series, G 27. Springer-Verlag, Berlin, p 61-99

Gieskes WWC, Kraay GW (1983) Dominance of Cryptophyceae during the phytoplankton spring bloom in the central North Sea detected by HPLC analysis of pignents. Mar Biol 75:179-185

Gieskes WWC, Kraay GW, Nontji A, Setiapermana D, Sutomo (1988) Monsoonal alternation of a mixed and a layered structure in the phytoplankton of the euphotic zone of the Banda Sea (Indonesia): a mathematical analysis of algal pigment fingerprints. Neth J Sea Res 22:123-137

Jeffrey SW (1974) Profiles of photosynthetic pigments in the ocean using thin-layer chromatography. Mar Biol 26. $101-110$

Jeffrey SW (1989) Chlorophyll $c$ pigments and their distribution in the chromophyte algae. In: Green JG, Leadbeater BSC, Diver WL (eds) The chromophyte algae: problems and perspectives. Systematics Assoc Spec Vol 38, Clarendon Press, Oxford, p 13-36

Jeffrey SW. Hallegraeff GM (1987) Chlorophyllase distribution in 10 classes of phytoplankton-a problem for chlorophyll analysis. Mar Ecol Prog Ser 35:293-304

Jeffrey SW, Vesk M (1997) Introduction to marine phytoplankton and their pigment signatures. In: Jeffrey SW. Mantoura RFC, Wnght SW (eds) Phytoplankton pigments in oceanography. Monographs on oceanographic methodology 10. UNESCO, Paris, p 37-84

Johnsen G, Samset O, Granskog L, Sakshaug E (1994) In vivo absorption characteristics in 10 classes of bloom-forming phytoplankton: taxonomic characteristics and responses to photoadaptation by means of discriminant and HPLC analysis. Mat Ecol Prog Ser 105:149-157

Keely BJ, Brereton RG (1986) Early chlorin diagenesis in a recent aquatic sediment. Org Geochem 10:975-980

Klein B, Riaux-Gobin C (1991) Algal pigment diversity in coastal sediments from Kerguelen (sub-Antarctic Islands) reflecting local dominance of green algae, euglenoids and diatoms. Polar Biol 11:439-448

Klein B, Sournia A. (1987) A daily study of the diatom spring bloom at Roscoff (France) in 1985. [I. Phytoplankton pigment composition studied by HPLC analysis. Mar Ecol Prog Ser 37:265-275

Krady GW, Zapata M, Veldhuis MJW (1.992) Separation of chlorophyll $c_{1}, c_{2}$ and $c_{3}$ of marne phiytoplankton by reversed-phase- $\mathrm{C} 18$ high performance luquid chromatography. J Phycol 28:708-712 
Levinton JS, McCartney M (1991) Use of photosynthetic pigments in sediments as a tracer for sources and fates of macrophyte organic matter. Mar Ecol Prog Ser 78:87-96

Millie DF, Paerl HW, Hurley JP (1993) Microalgal pigment assessments using high-performance liquid chromatography: a synopsis of organismal and ecological applications. Can J Fish Aquat Sci 50:2513-2527

Odum WE (1970) Utilization of the direct grazing and plant detritus food chains by the striped mullet Mugil cephalus. ln: Steele JH (ed) Marine food chains. Oliver \& Boyd, Edinburgh, p 222-240

Pastoureaud A, Heral M, Prou J, Razet D, Russu P (1996) Particle selection in the oyster Crassostrea gigas (Thunberg) studied by pigment HPLC analysis under natural food conditions. Oceanol Acta 19:79-88

Pennington FC, Haxo FT, Borch G, Liaaen-Jensen S (1985) Carotenoids of Cryptophyceae. Biochem Syst Ecol 13: $215-219$

Pinckney J, Papa R, Zingmark R (1994) Comparison of highperformance liquid chromatographic, spectrophotometric, and fluorometric methods for determining chlorophyll a concentrations in estuarine sediments. J Microbiol Meth 19:59-66

Plante-Cuny MR, Barranguet C, Bonin D, Grenz C (1993) Does chlorophyllide a reduce reliability of chlorophyll a measurements in marine coastal sediments? Aquat Sci 55: $19-30$

Quiblier C, Feuillade M, Bourdier G, Amblard C, Pépin D (1994) Phytoplankton distribution as determined by HPLC pigment analysis. Arch Hydrobiol Beih Ergebn Limnol 41:113-124

Riaux-Gobin C, Llewellyn CA, Klein B (1987) Microphytoben-

Editorial responsibility: Victor de Jonge (Contributing Editor), Haren, The Netherlands thos from two subtidal sediments from North Brittany. II. Variations of pigment compositions and concentrations determined by HPLC and a conventional technique. Mar Ecol Prog Ser 40:275-283

Rowan KS (1989) Photosynthetic pigments of algae. Cambridge University Press, Cambridge

Roy S, Chanut JP, Gosselin M. Sime-Ngando T (1996) Characterization of phytoplankton communities in the lower St. Lawrence Estuary using HPLC-detected pigments and cell microscopy. Mar Ecol Prog Ser 142:55-73

Stauber JL, Jeffrey SW (1988) Photosynthetic pigments in fifty-one species of marine diatoms. J Phycol 24:158-172

Stransky H, Hager A (1970) Das Carotinoidmuster und die Verbreitung des lichtinduzierten Xanthophyllcyclus in verschiedenen Algenklassen VI. Chemosystematische Betrachtung. Arch Mikrobiol 73:315-323

Venrick EL (1978) How many cells to count? In: Sournia A (ed) Phytoplankton manual. Monographs on oceanographic methodology 6. UNESCO, Paris, p 167-180

Vernet $M$, Lorenzen CJ (1987) The relative abundance of pheophorbide $a$ and pheophytin a in temperate marine waters. Limnol Oceanogr 32:352-358

Villanueva J, Grimalt JO, de Wit R, Keely BI, Maxwell JR (1994) Chlorophyll and carotenoid pigments in solar saltern microbial mats. Geochim Cosmochim Acta 58: $4703-4715$

Wright SW, Jeffrey SW, Mantoura RFC, Llewellyn CA, Bjornland T, Repeta D, Welschmeyer N (1991) Improved HPLC method for the analysis of chlorophylls and carotenoids from marine phytoplankton. Mar Ecol Prog Ser 77:183-196

Young AJ (1991) The photoreceptive role of carotenoids in higher plants. Physiol Plant 83:702-708

Submitted: August 27, 1997; Accepted: July 13, 1998

Proofs received from author(s): September 18, 1998 